\title{
Associating Students' Satisfaction and Quality of Graduate Educational Services in a Catholic Higher Educational Institution in the Philippines
}

\author{
Prof. Dr. Segundo Chavez Redondo, Jr. ${ }^{1}$, Prof. Dr. David Cababaro Bueno ${ }^{2}$, Prof. Dr. Rafael D. Mora ${ }^{3}$, \\ Prof. Dorana G. Berzo ${ }^{4}$ and Prof. Milagros C. Garcia ${ }^{5}$
}

\begin{abstract}
This study is conducted to gather empirical data to ascertain and link the quality of graduate education through students' satisfaction level during the Academic Year 20152016. The researchers used the descriptive cross-sectional design of research and descriptive statistical analysis. The professors are exerting more efforts to assist students in enhancing their research competencies. They utilize instructional procedures to encourage active faculty-student interaction. The support services for research, thesis and other requirements are provided. Admissions and registration policies are clearly contained in the catalogue. An open-shelf system is adopted in the library. The accounting staffs are honest in collecting and returning the right amount of fees from students. There is a specified room to provide privacy for academic consultation and advising. Technical personnel are always available in case of emergency or sudden breakdown of equipment. Auxiliary services are also made available for students. The degree of students' satisfaction is attributed by the continuous improvement in the graduate school since the beginning of its voluntary submission to external accreditation.
\end{abstract}

Keywords - Graduate education, students' satisfaction, basic services, appraisal, cross-sectional design, Columban College Inc., Philippines

\footnotetext{
${ }^{\mathbf{1}_{\text {The }}}$ first author is Principal of the Basic Education Department and concurrent Director of Research and Publications Office of Columban College, Inc.-Olongapo City, Philippines.

${ }^{\mathbf{2}}$ The second author is Dean of the Graduate School and concurrent Dean of College of Education, Arts and Sciences.

${ }^{\mathbf{3}}$ The third author is a non-teaching staff assigned at the Accounting Office.

${ }^{4}$ The $4^{\text {th }}$ author is Chief Librarian at the College.

${ }^{\mathbf{5}}$ The $5^{\text {th }}$ is currently the Director of Admissions and Registration Office at Columban College, Inc.
}

\section{INTRODUCTION}

Understanding student satisfaction is critical to educational institutions as it provides inputs towards developing better tools to reach the students. According to Sapri, Kaka, and Finch (2009), student experience and satisfaction matter to educational institutions and students. Students are important to universities; as such; their experiences or knowledge and understanding of the educational institutions must reflect their voices or judgment rather than as defined by the universities. The authors also indicate that measuring student experience using both satisfaction and importance ratings will enable the educational institutions to identify their current level of service quality. Satisfaction is a well-researched topic in both academic and non-academic (workplace) settings. In academic settings, students' satisfaction data helps colleges and universities make their curriculum more responsive to the needs of a changing marketplace (Eyck, Tews \& Ballester, 2009; Witowski, 2008). In making curriculum more effective and responsive, it is important to evaluate effectiveness measures concerning the curriculum of each college, department, and program (Ratcliff, 1992; Elliott \& Healy, 2001; Özgüngör, 2010; Peters, 1988; Billups, 2008; Aman, 2009). The effectiveness of a curriculum can be evaluated using direct performance measures (comprehensive exams, projects, and presentations) and by indirect performance measures (students' satisfaction with the curriculum) (Jamelske, 2009; Witowski, 2008). Students' satisfaction surveys are important in ascertaining whether colleges and universities are fulfilling their mission. It is well known that the most important product of educational institutions is qualified graduates. In order to best prepare students so that they are sought after by employers upon graduation, an effective curriculum is needed. Students must understand the value of their education and be satisfied with their overall experience in order to promote and support their higher educational institution as a student and as an alumnus. Satisfaction is a relevant measure because many studies have demonstrated that other factors being equal, satisfied individuals are likely to be willing to exert more effort than unsatisfied individuals (Bryant, 2006; Özgüngör, 2010). Thus, satisfied students are likely to exert more effort in their 
educational studies by taking actions such as regularly attending their classes and becoming more involved in their coursework and institution.

Satisfied students are more likely to be committed and continue their studies than unsatisfied students, who are likely to be less willing to regularly attend classes, and are more likely to quit their studies (Jamelske, 2009; Borden, 1995). Researchers have assessed students' satisfaction for many reasons: Several researchers have measured the levels of student satisfaction in order to examine accountability reporting and self-improvement purposes across departments and colleges; others have examined student satisfaction to determine if satisfaction ratings of college programs and services are associated with the satisfaction of the overall graduate education experience. Still others have investigated student satisfaction items related to issues such as student retention and attrition. Given the importance of student satisfaction levels at higher educational institutions, there has been a growing interest in examining factors affecting students' satisfaction. Graduate students' satisfaction has been conceptualized in a number of ways by researchers. For example, students' satisfaction was conceptualized as "satisfaction with experience" (Elliott \& Healy, 2001; Peters, 1988; Billups, 2008), "satisfaction with quality of instruction" (Aman, 2009), "satisfaction with advising" (Corts, Lounsbury, Saudargas, Tatum, 2000; Elliott, 2003; Olson, 2008; Peterson, Wagner, and Lamb, 2001), "satisfaction with online courses" (Banks \& Faul, 2007; Heiman, 2008; Beqiri, Chase, \& Bishka, 2010), "satisfaction with assessment" (Kane, 2005; Ross, Batzer, \& Bennington, 2002), "satisfaction campus-wide" (Benjamin \& Hollings, 1997), and "satisfaction with an academic department" (Corts et al., 2000). The above studies indicate that there is a growing body of literature on student perceptions of satisfaction. They also suggest that student satisfaction is a complex yet poorly articulated notion (DiBiase, 2004; Garcia-Aracil, 2009).

This study focuses on the approach of indirect performance measures or assessing satisfaction of graduate school students with the curriculum and other support services. Numerous researchers have investigated issues related to students' satisfaction (Astin, 1977; Bryant, 2009; DeShields, Kara, \& Kaynak, 2005; Pascarella \& Terenzini, 2005), and most of them agree that highly satisfied students are more likely to remain in, and ultimately, successfully graduate from college. Some research also reveals that student satisfaction is inversely related to student complaints regarding advising, career preparation, and the need for new courses or effectiveness of current courses (Korn, Sweetman, \& Nodine, 1996). In this study, however, satisfaction is conceptualized as "satisfaction with curriculum and other support services". Unlike prior studies, this study intends to contribute to existing literature by determining the extent to which twelve factors affect students' satisfaction by focusing on a sample of graduating students. Despite the many studies on student satisfaction with graduate-related issues, this student satisfaction survey is intended to assess the satisfaction of the graduate school students regarding faculty, curriculum and instruction, research, admissions and registration office, library, accounting office, and other resources and services to ascertain the quality of graduate education in a private higher educational institution.

Interest in factors affecting satisfaction has increased in both academic and non-academic settings. This is mainly due to the fact that satisfaction (motivation) affects both individual and organizational performance (Cranny et al., 1992; Decenzo \& Robbins, 2010). In the workplace, scholars have defined satisfaction in a number of ways (Locke, 1976; Robbins \& Judge, 2008). The central theme across studies involves a positive feeling of one's job resulting from an evaluation of its characteristics. Satisfaction in work environment has been studied both as an independent and a dependent variable. As an independent variable, satisfaction explains outcomes such as performance, absenteeism, and turnover (Cranny et al., 1992; Ramayah \& Nasurdin, 2006). As a dependent variable, satisfaction is explained by factors such as salary, benefits, and recognition (Ramayah \& Nasurdin, 2006; Tessema, Ready and Embaye, 2011). In academic settings, satisfaction has been defined as the extent to which students are satisfied with a number of related issues such as advising, quality of instruction, course availability, and class size.

According to Elliott and Healy (2001), student satisfaction is a short-term attitude based on an evaluation of their experience with the education service supplied. Just like in the workplace, satisfaction in academic settings is also treated as both an independent and dependent variable. For instance, satisfaction, as an independent variable, explains college outcomes such as GPA, retention rates, and graduation rates (Jamelske, 2009; Borden, 1995; Noel, 1978; Pascarella \& Terenzini, 2005). As a dependent variable, satisfaction is explained by a number of academic- related factors such as advising, quality of instruction, and class size (Corts, et al., 2000; Elliott, 2003; Peterson, et al., 2001). Several researchers have identified and empirically tested factors affecting or that are correlated with students' satisfaction. Since students' satisfaction has been conceptualized in a variety of ways by researchers, several factors have been examined that affect college students' satisfaction For instance, Corts et al. (2000) identified five factors affecting satisfaction with an academic department, and Elliott and Healy (2001) identified eleven factors affecting students' satisfaction with educational experience.

The College, as part of its Strategic Planning Initiative, has provided funding to support the Customer Focus (CF) activity to address this need for a systems level study of student services. The primary goals of the CF are to: 1) develop a systems level view of student services and their 
interrelationships; 2) identify systems level improvement opportunities, including re-engineering; 3) recommend changes and/or in-depth studies; and 4) develop implementation plans for changes and/or in-depth studies. As part of the CF activity, there is a need to determine the current importance and satisfaction levels of the students not only in the undergraduate level but similar with the graduate school level with respect to various student services to serve as a baseline to evaluate potential future improvements options. Thus, this investigation consisted of examining the results of surveys conducted to determine student satisfaction levels, identifying where additional surveys may be required, and evaluating how well surveys are currently being conducted. As a starting point, this report provided an inventory of student satisfaction survey that has been conducted at the graduate school. Thus, the survey is based on the various clusters/ scales summarizing the level of student satisfaction and the degree to which the surveys have been analyzed.

\section{OBJECTIVE OF THE STUDY}

This study is conducted with following objectives: (1) To gather empirical data relative to graduate school students' satisfaction level regarding faculty, curriculum and instruction, research, admissions and registration office, library services, accounting office, and other resources and services, and (2) To improve the curriculum and instruction, and the basic services of the institution to its clientele.

\section{METHODOLOGY}

The researchers used the descriptive cross-sectional design of research. According to Gay, (1996) it involves collecting data in order to answer questions concerning the status of the subject of the study; it is typically collected through a questionnaire survey, an interview or observation in a specified time. Closed-ended questions were employed by the researchers. Heiman, (1998) stressed that the closeended or objective question has an overwhelming strength. A response can be assigned objectively and reliably with a minimum of subjective interpretation or error on the researcher's part. Best and Khan, (1989) further discussed that this type of study conceals an important distinctions. It describes and interprets what is concerned with conditions or relationships that exist, opinions that are held, processes that are going on, effects that are evident, or trends that are developing. It is primarily concerned with the present, although it often considers past events and influences as they relate to current conditions. The senior and graduating students during the Academic Year 2016-2017 were all considered to answer the satisfaction survey instrument. The instrument was administered to all senior and graduating students through a face-to-face invitation. This was done on June 2016 to February 2017. In this study, a close-ended survey was used to obtain demographic information and data about the students' satisfaction level from the graduate school program they are pursuing. The participants were informed about their voluntary involvement in the study. Thus, the researchers carefully explained the major purpose and objective of the study. The participants were assured with the anonymity of their identification, and were not forced to answer the survey form. The items of this survey were forced choice and a five-point Likert type scale (from 5 = "Very satisfied" to 1 $=$ "Very dissatisfied") was used to measure the participant's level of satisfaction. The statements included in the questionnaire were clearly stated and aimed at obtaining the needed information about the level of satisfaction from the school services and facilities. For the internal consistency and reliability, they measured the Cronbach's alpha, which is a method of estimating internal reliability. The researchers got a Cronbach's alpha coefficient of 0.982 for the items. The Cronbach's alpha should be greater than 0.7 , so this questionnaire is reliable (Bueno, 2017).

\section{RESUlTS AND DisCUSSION}

\section{A. Faculty}

The level of satisfaction of graduate school students relative to faculty is reflected. As reflected, the students "strongly agree" that the faculty members in the graduate school maintain professional relationships with students, other faculty and the dean, manifest awareness of modern educational trends, assist graduate students in developing research competencies, prepare well for their classes, show mastery of subject matter, relate current issues and community needs with their subject matter, use library resources and other instructional materials, and provide academic advising for students. This means that the graduate students are very satisfied as regards to various indicators concerning faculty of the graduate school. The average rating is 4.54 which mean "Very Satisfactory". Social and physical factors of an institution's services may greatly influence the degree of attractiveness and the students' overall satisfaction. Social factors consist of student-faculty member's relationships, studentadministration member's relationships and student-student relationships. Then, physical factors represent the class size and the environment, technology used during the lectures, library and computer laboratory, Wi-Fi connections in the campus, cafeteria and all student related service facilities. Considering the fact that all such services may have an impact on the students' attitude toward the institution and their satisfaction, in relatively small size non-profit private higher education institutions, educators have tried to maximize the services derived especially from social factors. The students can come and meet any time with their course instructor as well as with their academic advisor if available (Ali, 2011), and the growing up of qualified manpower was expected generally from 
universities, especially from post graduate teaching programs. To reach the goals of a post graduate program it is important to bring out the perceptions of self-efficacies of students about the field they studied during their post graduate education (Vekkaila, Pyhältö, \& Lonka, 2013). Research, learning and teaching are basic component of student's especially in graduate levels and they have critical roles in improving educational processes to develop scientific products in society (Gorji, Darabieniya, \& Ranjbar, 2015). Having and honing the research skills that encompass every level of research in various graduate disciplines is a key to an undergraduate developing the foundation for a successful career in research (Showman et al., 2013).

\section{B. Curriculum and Instruction}

Curriculum and instruction as area of students' satisfaction is shown. The average rating given by the student is 4.80 with a descriptive rating of "Very Satisfactory). The result implies that program's goals and objectives are well-defined; program's course requirements are appropriate and provide adequate preparation for subsequent courses and are reflected in the syllabi. Program's curriculum provides a balanced scope of material needed for overall graduate-level competency in my area of specialization; courses are offered regularly and as scheduled; instructional procedures and techniques in the classroom encourage active faculty and student interaction; evaluation activities measure the attainment of objectives stated in the syllabi; and the quality of curriculum and instruction is very satisfying. These findings were reinforced by Bueno (2017), when he concluded that the faculty in graduate school were outstanding in achieving the objectives of the graduate program by showing mastery of subject matter, relating current issues and community needs, and participating the activities of professional organizations. Moreover, Bueno (2017), elucidated in terms of instructional procedures and techniques as standards, the faculty members were outstanding in providing opportunities for independent study, utilizing instructional materials with depth and breadth expected for the graduate level, requiring students to make extensive use of print and non-print reference materials, using instructional procedures and techniques to encourage active students' interaction; using interdisciplinary and/or multidisciplinary approaches whenever possible; and enforcing definite rules and policies for effective classroom management. However, they were very satisfactory in providing a functional and well-planned syllabus which specifies the target competencies, research and class activities required for course, and in using varied methods and innovative approaches (seminars, fora, field observations, problembased discussion).

\section{Research}

Data reveals the satisfaction rating given by the students on research area. As reflected, the average rating is 4.70 with a descriptive rating of "Very Satisfactory". This implies that in the graduate school, the faculty members teaching research courses or assigned thesis advising have adequate experience; research is an integral part of all course requirements; results are made available for students to help them gain self-understanding; research seminars, workshops and lectures for students are regularly offered; materials and guidelines are provided for the development of research skills; sufficient statistical assistance for research is provided by qualified faculty or staff.; research abstracts are published as monographs or appear in institutional and/or professional journals; intellectual honesty and creativity are values that the school emphasizes; and there are support services for research, thesis and other requirements, like critiquing and editing for language and format of research reports. Quality has become one of the key elements of the Millennium Development Goals (MDGs). Quality in education aims at bringing the attention to the education for human rights and also emphasize the importance of the economic, social and environmental grounds of a certain area. The definition of quality in higher education is to certain extend complex, although sometimes it is easy to identify it from a multidimensional perspective including teaching, research, staff-students relationships, services and facilities (Rahman $\&$ Zarim, 2014). Thus, all the universities should have a moral obligation to improve and contribute to the social, intellectual, cultural and economic background of the individuals in the society. In doing so, universities contribute to both the intellectual vitality and the economic well-being of society; produce educated citizens; train the next generation of leaders in the arts, sciences, and professions; and actively engage in community service activities that bring faculty knowledge and research findings to the attention of citizens and industry (Türkiye, Prof, \& Caglar, 2014). Moreover, numerous research have pointed out that there are high proportions of graduate student who fail to complete their studies within the time given. Many factors contributing to this and the major problem is related to the supervisory contribution (Showman et al., 2013). Their needs in this particular matter are always become a conflict as they did not have any other sources in guiding them to go through their studies (Eduljee \& Lebourdais, 2015). Lack of studentsupervisor relationship will caused them to extend their studies and have difficulty to finish their project (Abiddin \& Ismail, 2011). This situation will also lead to a poor quality of students' research (Japos \& Tumapon, 2010). Whilst the interaction between supervisor and student allows a considerable degree of free expression, it is enacted within a wider context of institutional power which itself is continuously modified by that interaction (Heidarigorji, Ghorbani, Darabi, \& Ranjabr, 2016). Supervision is a 
complex social encounter which involves two or more parties with both converging and diverging interests (Kurbanoglu, Akkoyunlu, \& Umay, 2006). Therefore, balancing these interests is very crucial to the successful supervision of postgraduate research projects.

\section{Admissions and Registration Office.}

Data depicts the degree of satisfaction of graduate students relative to admissions and registration office. As reflected, the rating is 4.59 with a descriptive rating of "Very Satisfactory". This reveals that the policies of the selection and admission of students reflect the institutional objectives and are strictly enforced; the retention policies and criteria are clearly stated and made known to the students; policies and procedures are contained in the school's catalogue or bulletin of information; the staff are prompt in releasing requested credentials; the staff are accommodating to the needs of the students; the staff uphold confidentiality of students' records; and the services of the staff are very satisfying. Bueno (2017), emphasized that the school-related factors relevant to graduates' employment statuses are collectively grouped to administration and governance, curriculum and instruction, research subjects, professional and cognate courses, student services like the admission and registration services office, library, internet laboratory, inter-disciplinary learning, and teaching/ learning environment are the related factors which contributed a lot to their current employment status. The results reveal that the presence of these relevant factors really hones their knowledge, skills, and values which are considered by them as a very important instrument for land in various prestigious jobs among the graduates.

\section{E. Library}

Data reveals the degree of satisfaction of graduate students relative to library. As reflected, the rating is 4.60 with a descriptive rating of "Very Satisfactory". This result implies that there are professional librarians to meet the needs of the students; reading materials and references in print and / or non-print formats are easily accessible; the collection of books, periodicals and other library materials are adequate to support the demands for research and instruction; the written policies covering acquisition and utilization of books, periodicals and non-print materials are enforced; the library maintains regular and adequate hours of service on the class days and non- class days; the library provides an atmosphere conducive for reading, study and research; the open-shelf system is adopted; and the service of the staff is very satisfying. Important developments and changes occurring in science and technology have influenced the field of education as well. New paradigms have been shaped in learning and teaching processes and strategies as a result of these changes (Ahmed, 2011). Education as a service is provided by the educators who consider both physical and social environment to positively influence student satisfaction (Saif, 2014). Since the education system has undergone through many changes due to science and technology advancement, so do change all the components of education. Today staff and professors take the role of following, guiding and supporting the students' learning process accompanied with sufficient library resources (Budiendra, Wandebori, \& Marketing, 2012). Moreover, nowadays academic libraries need to be ahead of other information service providers to ensure their existence. They need to know their users' needs and wishes, have to work effectively and efficiently, and especially should be able to anticipate the future of information services and management needs for the students (Düren, 2012); sustainable areas must be taken into consideration in evaluating library's sustainability regarding the space, green IT, strategies, collection management, location and environmental awareness of both public and staff (Karioja, 2013); and the library being the most essential pillar of any academic institution needs utmost attention to avoid total collapse of the entire university community (Salman, 2013). That is why, Ogunmodede, and Ebijuwa (2013), emphasized that the libraries in third world countries despite the constraints of finance confronting them still make huge investment on acquisition of library resources, and the deterioration of library resources has been one of the greatest challenges plaguing the libraries.

\section{F. Accounting Office}

The degree of satisfaction of graduate students relative to accounting office is reflected. The rating is 4.51 with a descriptive rating of "Very Satisfactory". The result implies that the members of the accounting staff are prompt in releasing requested information for payments during enrolment; friendly, approachable and respectful to students; honest in collecting and returning the right amount of fees of students; provides accurate information regarding school fees; and shows evidence of orderliness and systematic work management. The understanding of satisfaction that appears to underpin these somewhat crude measures is a very narrow one. It equates with a form of contentment, with the positive and happy feelings that derive from everything being settled within the school environment with responsive accounting staff and personnel (Tasirin, Omar, Esa, Zulkifli, \& Amil, 2015). Bueno (2017) further emphasized that the school-related factors relevant to graduates' employment statuses are collectively grouped to administration and governance, and the student services like the accounting office staff, and other areas such as the library, laboratories, interdisciplinary learning environment are the related factors which contributed a lot to the graduates' employability.

\section{G. Other Resources and Services}

The degree of satisfaction of graduate students relative to other resources/ services is reflected. The rating is 4.66 
with a descriptive rating of "Very Satisfactory". This result implies that photocopying facilities are readily available in school. There are enough classrooms readily available for classes, comprehensive and oral examinations. Moreover, there is consultation room which provides privacy in the graduate school; there is an internet laboratory for easy website access; and there is a canteen that serves nutritious, safe, well-balanced and reasonably priced meals. Furthermore, the school has maintenance and security personnel; technical personnel are available in case of emergency or sudden breakdown of equipment; there is a functional academic advising system for the graduate students from start until completion of their graduate programs; and auxiliary services such as guidance, dental, medical, religious are made available for students. To achieve good results in higher education, it is important to know what other things and resources are required of students in the learning process. In today's competitive academic environment where students have many options available to them, factors that enable educational institutions to attract and retain students should be seriously studied (Fitri \& Hasan, 2008). Higher educational institutions are putting a lot of emphasis on understanding and attempting to improve student satisfaction due to current competitive pressures in the industry (Kara et al., 2016). In such an environment with sufficient educational services, the students find opportunity to become more familiar with each-other, more helpful and spent much more time with each-other at the university campus. When an educational setting aims at keeping the student in the focus of its services, then each component of the social environment contributes toward student satisfaction (Songsathaphorn, Chen, \& Ruangkanjanases, 2014). They are also encouraged to participate in indoor activities where most of them are part of a student organization. All the faculty members are willing to help the students find connections for their internship opportunities and match them with a study program at a top university abroad. Having a relatively small number of students in a certain field of study, makes it easier to spend more quality time one-on-one with the students (Al-alak, Salih, \& Alnaser, 2012).

\section{CONCLUSIONS AND RECOMMENDATIONS}

The graduate school students are very satisfied in relation to various factors such as faculty, curriculum and instruction, research, admissions and registration office, library, accounting office, and other resources and services. The degrees of satisfaction of students are attributed by the continuous improvement in the graduate school since the beginning of its voluntary submission to PACUCOA accreditation. Educational institutions can address these issues by allocating more resources to hire the right staff and to provide training and staff development programs to enable staff to continuously satisfy students. Teaching staff should also reflect their willingness to assist students and be more approachable; not just in the classroom, but also by providing some consultation hours that are flexible to students. Even though students place less importance on physical facilities, these facilitate the interaction process. As such, providing comfortable and conducive learning environment can enhance the core service provided by educational institutions. Quality and sustainability are emerging as themes that are rapidly spreading within higher educational institutions. The results of this study indicate that quality is vital to students. Educational institutions need to focus on the factors that can be linked to quality education and to be able to sustain them in the future. With regards to quality improvement, educational institutions may consider introducing quality standards for explicit services and enhancing the quality of teaching and learning aspects. It is important for educational institutions to actively monitor the quality of services they offer and to commit to continuous improvements. Continue the best practices in the graduate school both academic and nonacademic factors for the benefits of the stakeholders. The faculty of the graduate school may exert more efforts to assist graduate students in developing research competencies. They may likewise encouraged students to use library resources and other instructional materials. The faculty members may always make use of instructional procedures and techniques in the classroom to encourage active faculty- student interaction. Regular research seminars, workshops and lectures for students may be conducted and evaluated. The admissions and registrations staff may continue being prompt and accommodating to the needs of students. A regular acquisition and collection of books, periodicals and other library materials may be continuously done. The accounting staff may always manifest being friendly, approachable and respectful to students. Technical personnel always be available in case of emergency or sudden breakdown of equipment. The internet laboratory and services always be updated for easy and faster website access. Regular survey of graduate students' satisfaction level be done to improve services given to them.

\section{ACKNOWLEDGMENT}

The authors acknowledge the assistance of the research coordinators, faculty from the basic education and college, non-teaching staff, for the distribution and retrieval of the survey form and the Research and Publications Office of the Columban College, Inc. for funding the study. 


\section{REFERENCES}

[1] Ahmed, I. (2011). Student' s perspective of service quality in higher learning institutions: An evidence based approach. International Journal of Business and Social Sciences, 2(11), 159-164.

[2]Al-alak, B. A., Salih, A., \& Alnaser, M. (2012). Assessing the relationship between higher education service quality dimensions and student satisfaction professor of marketing college Of business management and accounting department. Australian Journal of Basic and Applied Sciences, 6(1): 156-164.

[3]Ali, A. (2011). Key factors for determining student s' satisfaction in distance learning courses: A study of Allama Iqbal Open University. Contemporary Educational Technology,2(2), 118134.

[4]Aman, R. R. (2009). Improving student satisfaction and retention with online instruction through systematic faculty peer review of courses. An unpublished doctoral dissertation. Oregon State University. AAT 3376735.

[5]Astin, A. W. (1977). Four critical years. San Francisco: JosseyBass.

[6]Banks, A. C. \& Faul, A. C. (2007). Reduction of face-to-face contact hours in foundation research courses: Impact on student knowledge gained and course satisfaction. Social Work Education, 26(8), 780-793. https://doi.org/10.1080/02615470601140500

[7]Bean J. P., and Vesper, N. (1994). Gender differences in college student satisfaction. Association for the Study of Higher Education Conference Paper, Tucson.

[8]Benjamin, M. \& Hollings, A. (1997). Student satisfaction: Test of an ecological model. Journal of College Student Development.

[9]Beqiri, M. S., Chase, N. M., \& Bishka, A. (2010). Online course delivery: An empirical investigation of factors affecting student satisfaction. Journal of Education for Business, 85(2), 95-100. https://doi.org/10.1080/08832320903258527

[10]Billups, F. D. (2008). Measuring college student satisfaction: A multi-year study of the actors leading to persistence. Paper presented at the 39th annual meeting of the Northeastern Educational Research Association, October 23, 2008, Rocky Hill, CT.

[11]Borden, V. M. H. (1995). Segmenting student markets with a student satisfaction and priorities survey. Research in Higher Education. https://doi.org/10.1007/BF02207767

[12]Bryant, J. L. (2006). Assessing expectations and perceptions of the campus experience: The Noel-Levitz Student Satisfaction Inventory. New Directions for Community Colleges, 134. San Francisco: Jossey-Bass.

[13]Bryant, J. L. (2009). Linking Student Satisfaction and Retention. Retrieved on March 4, 2011 from https://www.noellevitz.com/NR/rdonlyres/A22786EF-65FF4053-A15A CBE145B0C708/0/LinkingStudentSatis0809.pdf

[14]Budiendra, R. P., Wandebori, H., \& Marketing, A. S. (2012). Influence of Facility and Service Quality on Faculty of Pharmacy Student Satisfaction. Business, Economics, Management and Behavioral Sciences, 13(12), 70-74.

[15] Bueno, D. (2017). Research Skills of the Professorial Lecturers: Input to Capability Building. JPAIR Institutional Research, 9(9), 1-17. doi:10.7719/irj.9i9.489

[16] Bueno, D. (2017). Ascertaining the Curriculum Relevance of the Graduate School through Tracer Study in a Philippine Private Higher Education Institution. JPAIR Multidisciplinary Research, 28(1). doi:10.7719/jpair.v28i1.502

[17]Cassidy, S \& Eachus, P. (2002). Developing the computer user self-efficacy (CUSE) scale: Investigating the relationship between computer self-efficacy, gender and experience with computers. Journal of Educational Computing Research, 2(5), 24-31. https://doi.org/10.2190/JGJR-0KVL-HRF7-GCNV

[18]Chee, K. H., Pino, N. W., and Smith, W. L. (2005). Gender Differences in the Academic Ethic and Academic Achievement. College Student Journal.

[19]Cohen, J. (1988). Statistical power analysis for the behavioral sciences (2nd edition). Hillsdale, NJ: Erlbaum.

[20]Corts, D. P., Lounsbury, J. W. Saudargas, R. A., Tatum, H. E. (2000). Assessing undergraduate satisfaction with an academic department: A method and case study. College Student Journal, 34 (3), 399-410. International Journal of Humanities and Social Science, 2(2) [Special Issue - January 2012]

[21[Cranny, C. J., Smith, P. C., \& Stone, E. F. (Eds.). (1992). Job satisfaction: How people feel about their jobs and how it affects their performance. New York: Lexington Books.

[22]Dahlgren, M. A., Hult, H., Dahlgren, L. O., Segerstad, H. H., \& Johansson, K. (2006). From senior student to novice worker: Learning trajectories in political science, psychology and mechanical engineering. Studies in Higher Education, 1(6), 1237 https://doi.org/10.1080/03075070600923400.

[23]DeCenzo, D. A., \& Robbins, S. P. (2010). Fundamentals of human resource management (10th Ed.). Hoboken, NJ: John Wiley \& Sons, Inc.

[24]DeShields, O. W., Kara, A., \& Kaynak, E. (2005). Determinants of business student satisfaction and retention in higher education: Applying Herzberg's two-factor theory. International Journal of Educational Management, 6(3), 67-79. https://doi.org/10.1108/09513540510582426

[25]DiBiase, D. (2004). The Impact of increasing enrolment on faculty workload and student satisfaction over time. Journal of Asynchronous Learning Networks.

[26]Düren, P. (2012). Total Quality Management in Academic Libraries - Best Practices. Qualitative and Quantitative Methods in Libraries (QQML), 1, $43-50$

[27]Elliot, K. M., \& Healy M. A. (2001). Key factors influencing student satisfaction related to recruitment and retention. Journal of Marketing for Higher Education, 8(2), 17-29 https://doi.org/10.1300/J050v10n04_01.

[28]Eyck, R., Tews, M., \& Ballester, J. M. (2009). Improved Medical Student Satisfaction and Test Performance with a Simulation-Based Emergency Medicine Curriculum: A Randomized Controlled Trial. Paper presented at the ACEP 2008 Research Forum, October 2008, Chicago, IL.

[29]Fitri, H., \& Hasan, A. (2008). Service Quality and Student Satisfaction: A Case Study at Private Higher Education Institutions, CCSE International Business Research Journal, $163-175$.

[30]Garcia-Aracil, A. (2009). European graduates' level of satisfaction with higher education. Higher Education, 4(2), 121137. https://doi.org/10.1007/s10734-008-9121-9

[31]Gordon, V. N. (2005). Career advising: An academic adviser's guide. San Francisco: Jossey-Bass.

[32]Guinn, D., \& Mitchell, R. (1985). Academic advising: And different expectations. NACADA Journal

[33]Hanna, D. E., Glowacki-Dudka, M., \& Runlee, S. (2000). 147 practical tips for teaching online groups. Madison, WI: Atwood Publishing.

[34]Heiman, T. (2008). The effects of e-mail messages in a distance learning university on perceived academic and social support, academic satisfaction, and coping. Quarterly Review of Distance Education, 3(5), 79-88. 
[35]Henson, R. K. (2001). Understanding internal consistency reliability estimates: A conceptual primer on coefficient alpha. Measurement and Evaluation in Counselling and Development.

[36]Hossain, M., \& Rahman, M. (2013). Service quality and student satisfaction: a case study on private universities in Bangladesh. International Journal of Economics, Finance and Management Sciences, 1(3), 128-135. doi: 10.11648/j.ijefm.20130103.11

[37]Hurtig, J.K. Estell, J.K. (2009). A common framework for diverse capstone experiences. Frontiers in Education Conference, 2009. FIE '09. 39th IEEE, San Antonio, TX. https://doi.org/10.1109/FIE.2009.5350460

[38]Jamelske, xx (2009). Measuring the impact of a university firstyear experience program on student GPA and retention. Higher Education Research, 9(2), 21-34. https://doi.org/10.1007/s10734-008-9161-1

[39]Kane, K. (2004). Quality matters: Inter-institutional quality assurance in online learning. Sloan-C View: Perspectives in Quality Online Education.

[40]Kara, A. M., Narok, P. O. B., Tanui, E., Ph, D., Narok, P. O. B., Kalai, J. M., \& Ph, D. (2016). Educational Service Quality and Students 'Satisfaction in Public Universities in Kenya. International Journal of Education and Social Sciences, 3(10), $37-48$.

[41]Karioja, E. (2013). Sustainability in libraries. A comparative study of ecological sustainability in IFLA WLIC 2012. Oulu University of Applied Sciences. Retrieved on May 21, 2013 from: http://urn.fi/URN:NBN:fi:amk-201305025876

[42]Korn, J. H., Sweetman, M. B., Nodine, B. F. (1996). An analysis of and commentary on consultants' reports on undergraduate psychology programs. Teaching of Psychology. https://doi.org/10.1207/s15328023top2301_2

[43]LPC (Las Positas College) (2009). Research Brief Office of Research and Planning. Retrieved on December 14 from http:// www.laspositascollege.edu/researchandplanning/documents/ Fall2007StudentSatisfactionSurveySelectedInclusionSatisfaction VariablesbyGenderandRace.pdf

[44]Lunnenborg, P. W., \& Wilson, V. M. (1985). Would you major in psychology again? Teaching of Psychology.

[45]McAnulty, B. H., O'Connor, C. A., \& Sklare, L. (1987). Analysis of student and faculty opinion of academic advising services. NACADA Journal. https://doi.org/10.12930/0271-9517-7.1.49

[46]McGovern, T. V., \& Hawks, B. K. (1986). The varieties of undergraduate experience. Teaching of Psychology https://doi.org/10.1207/s15328023top1304_1.

[47]Moro-Egido, A. I. and J. Panades (2010). An Analysis of Student Satisfaction: Full-Time versus Part-Time Students. Social Indicators Research, 7(2), 31-43. https://doi.org/10.1007/s11205-009-9482-1

[48]Norcross, J. C., Gerrity, D. M., \& Hogan, E. M. (1993). Some outcomes and lessons from a cross-sectional evaluation of psychology undergraduates. Teaching of Psychology, 20, 93-96 https://doi.org/10.1207/s15328023top2002_6.

[49]Ogunmodede, Thomas A. and Ebijuwa, Adefunke Sarah (2013). Problems of Conservation and Preservation of Library Resources in African Academic Libraries: A Review of Literature. Greener Journal of Social Sciences, 3 (1),50-57. https://doi.org/10.15580/GJSS.2013.1.112412291

[50]Olson, J. S. (2008). Career Development, the Undergraduate, and the Academic Adviser. The Mentor: An Academic Advising Journal. Retrieved on March 4, 2011 from: http://dus.psu.edu/mentor/081015jo.htm

[51] Özgüngör, S. (2010). Identifying Dimensions of students' ratings that best predict students' self-efficacy, course value and satisfaction. Eurasian Journal of Educational Research, 8(2), 6977.
[52]Palloff, R. M., \& Pratt, K. (2001). Lessons from the cyberspace classroom - The realities of online teaching. San Francisco, CA: Jossey-Bass.

[53]Parayitam, S., Desail, K, and Phelps, L. (2007). The Effect of Teacher Communication and Course Content on Student Satisfaction and Effectiveness. Academy of Educational Leadership Journal, 9(2), 86-95.

[54]Pascarella, E. T., \& Terenzini, P. T. (2005). How college affects students: A third decade of research, Vol. 2. San Francisco: John Wiley \& Sons.

[55]Perry, M. J., Sekelsy, M. J. \& Skarsten, F. (March, 2003). University of Michigan-Flint Student Satisfaction Surveys Results. Retrieved March 4th, 2011, from http://www.vca.umflint.edu/.The Special Issue on Contemporary Research in Behavioral and Social Science

[56]Peterson, M., Wagner, J. A., \& Lamb, C. W. (2001). The role of advising in nonreturning students' perceptions of their university. Journal of Marketing for Higher Education. https://doi.org/10.1300/J050v10n03 03

[57]Rahman, M. S., \& Zarim, A. (2014). Service Quality and Students' Satisfaction Towards Purchasing Online Educational Resources. European Journal of Business and Social Sciences, 1(2), 57-64.

[58]Ramayah, T., \& Nasurdin, A.M. (2006). Integrating importance into the relationship between job satisfaction and commitment: A conceptual model. The ICFAI Journal of Organization Behavior.

[59]Ratcliff, J.L., (ed.) (1992) Assessment and Curriculum Reform: New Directions for Higher Education. No.80. JosseyBass Inc., Publishers, San Francisco, California.

[60]Renzi, B. M., Allen, M. J., Sarmiento, Y. Q. \& McMillin, J. D. (1993). Alumni perception of the impact of gender on their university experience. Journal of College Student Development.

[61]Russell, M. and Lehman, A. (2008). Predicting Student Satisfaction with Academic Advising. The Mentor: An Academic Advising Journal, 10 (1) (January-March, 2008).

[62]Saif, N. I. (2014). The Effect of Service Quality on Student Satisfaction: A Field Study for Health Services Administration Students. International Journal of Humanities and Social Sciences, 4(8), 172-181.

[63]Salman A.A (2013). Appraisal of Academic Library Standards as Measurements for Nigerian Academic Libraries. Dept. of Library and Information Science, International Jnr. of Faculty of Communication and Information Sciences, University of Ilorin, Ilorin Nigeria, 1, (1), 152-156.

[64]Sampson, S. F; Leonard, J.; Ballenger, J. W; Coleman, J. C. (2010). Student Satisfaction of Online Courses for Educational Leadership. Online Journal of Distance Learning Administration, Volume XIII, Number III, Fall 2010

[65]San Diego, CA, May 2005. Obtained at http://www.heri.ucla.edu/PDFs/SaxHarper_GenderGap_Air05.PDF on March 4, 2011.

[66]Sapri, M., Kaka, A., and Finch, E., (2009) "Factors that influence Student's Level of Satisfaction With Regards to Higher Educational Facilities Services", Malaysian Journal of Real estate, 4(1), 34-51

[67]Sax, L. J. and Harper, C. E. (2005). Origins of the Gender Gap: Pre-College and College Influences on Differences between Men and Women. Paper presented at the Annual Meeting of the Association for Institutional Research,

[68]Schmidt, S., Strachota, E., \& Conceição, S. (2005). Conducting Online Survey Research. Milwaukee, WI: Midwest Research-toPractice Conference in Adult, Continuing, and Community Education.

[69]Seaberry, B. J. (2008). A case study of student and faculty satisfaction with online courses at a community college. An 
unpublished doctoral dissertation. University of California, Davis.

[70]Sheehan, K.B. (2001). E-mail survey response rates: A review. Retrieved May 22, 2006 from: http://www.ascusc.org/jcmc/vol6/issue2/sheehan.html

[71]Songsathaphorn, P., Chen, C., \& Ruangkanjanases, A. (2014). A Study of Factors Influencing Chinese Students 'Satisfaction toward Thai Universities. Journal of Economics, Business and Management, 2(2). https://doi.org/10.7763/JOEBM.2014.V2.107

[72]Strachota, E. (2003). Student satisfaction in online courses: An analysis of the impact of learner-content, learner-instructor, learner-learner and learner-technology interaction. Doctoral dissertation, University of Wisconsin-Milwaukee. Ann Arbor, Michigan, UMI Publishing.

[73]Tasirin, S. M., Omar, M. Z., Esa, F., Zulkifli, N. M., \& Amil, Z. (2015). Measuring student satisfaction towards engineering postgraduate program in UKM. Journal of Engineering Science and Technology, 1, 100-109.

[74]Tessema, M., Ready, K., and Embaye, A. (2011). the Effects of Employee Recognition, Pay, and Benefits on Job Satisfaction: Cross Country Evidence. Paper presented at MBAA conference, Chicago March 23-25, 2011.

[75]Tinto, V. (1987). Leaving college: Rethinking causes and cures of student attrition. Chicago: The University of Chicago.

[77]Türkiye, E., Prof, A., \& Caglar, A. (2014). Service Quality and Customer Satisfaction Relationship: A Research in Erzurum Ataturk University Refectory. American International Journal of Contemporary Research, 4(1), 100-117.

[78]Umbach, P. D. \& Porter, S. R. (2002). How do academic departments impact student satisfaction? Research in Higher Education, 9(3), 35-49.

[79]Wilder, J. R. (1982). Academic and career advising: Institutional commitment and program recommendations [Electronic version]. Peabody Journal of Education, 3(2), 37-51. https://doi.org/10.1080/01619568209538360

[80]Witowski, L. (2008). The relationship between instructional delivery methods and students learning preferences: What contributes to students' satisfaction in an online learning environment? Ph.D. Dissertation. Retrieved on December 11, 2010 from http:// gradworks.umi.com/ 3310726.pdf

[81]Abiddin, N. Z., \& Ismail, A. (2011). Effective Supervisory Approach in Enhancing Postgraduate Research Studies. International Journal of Humanities and Social Science, 1(2), 206-217.

[82]Eduljee, N. B., \& Lebourdais, P. (2015). Gender Differences in Statistics Anxiety with Undergraduate College Students, 2(3).

[83]Gorji, A., Darabieniya, M., \& Ranjbar, M. (2015). Research selfefficacy in relation to educational motivation in students of Mazandaran University of Medical Sciences. Journal of Contemporary Medical Education, 3(2), 1. https://doi.org/10.5455/jcme.20150704093825

[84]Heidari-gorji, A. M., Ghorbani, A., Darabi, M., \& Ranjabr, M. (2016). Survey of Research self-efficacy of postgraduate Nursing students in Mazandaran university of Medical Science - Northern Iran, 1-3.

[85]Japos, G. V, \& Tumapon, T. T. (2010). Reinventing Graduate Instruction in a Web Environment, 6(2), 349-358.

[86]Kurbanoglu, S. S., Akkoyunlu, B., \& Umay, A. (2006). Developing the information literacy self-efficacy scale. Journal of Documentation, 62(6), 730-743. https://doi.org/Doi $10.1108 / 00220410610714949$

[87]Showman, A., Cat, L. A., Cook, J., Holloway, N., Wittman, T., \& Karukstis, K. K. (2013). Five Essential Skills for Every Undergraduate Researcher. Council on Undergraduate Research Quarterly, 33(3), 16-20.

[88]Vekkaila, J., Pyhältö, K., \& Lonka, K. (2013). Focusing on doctoral students ' experiences of engagement in thesis work, 2, $12-34$.

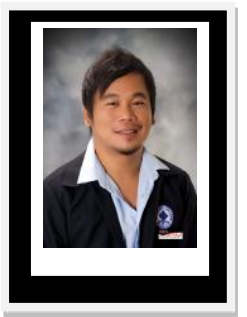

Prof. David Cababaro Bueno is a holder of Doctor of Education, Master of Arts in Science Education, Master in Public Management, Master in Business Administration, and Bachelor of Arts degrees. He is a candidate for graduation leading to the degree of Doctor in Business Administration and currently taking Doctor in Public Management.

He authored and co-authored books in Research Writing, Statistics, Biological, Physical and Environmental Sciences, Human Resource Management, Organization and Management, and Curriculum Development. He is currently the Dean of the Graduate School and concurrent Director of Research and Publications at Columban College, Inc. Dr. Bueno is an active member of various national and international professional organizations, research technical committee and reviewer of various international conferences, seminar-workshop speaker and multi-awarded research presenter in the ASEAN community.

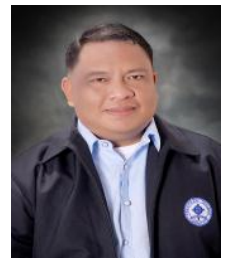

Dr. Redondo is Principal of the Basic Education Department and concurrent Director of Research and Publications Office of Columban College, Inc.Olongapo City.

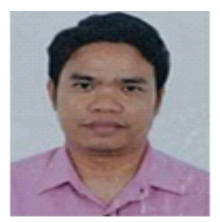

Prof. Dr. Rafael D. Mora is a holder of BSA, MBA and Doctor of Education (Ed.D.) in Educational Administration. $\mathrm{He}$ is an accredited assessor of the TESDA certification for Bookkeeping NCIII. Dr. Mora is also currently working as accountant at the Accounting

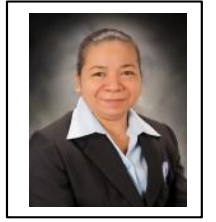

Prof. Berzo is currently the Chief Librarian at Columban College, Inc. She Obtained degrees in Library Science in both undergraduate and graduate levels.

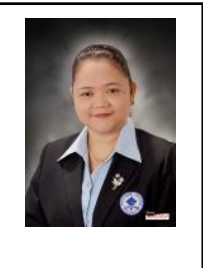

Prof. Garcia obtained her degree in Business Administration both in the undergraduate and graduate levels. She is currently the Director for Admissions and Registration Office. 